\title{
A Conceptual Account of Market Morals that Resonated in Medieval Anatolia under Christian and Muslim Rule
}

\author{
İklil Selçuk*
}

This paper surveys several prescriptive, descriptive and narrative sources of moral conduct from patristic teachings to Islamic commanding good and futuwwa (t. fütüvvet) that had resonating effects on the definition of appropriate behavior in urban markets in medieval Anatolia. The purpose of this scrutiny is to highlight converging notions among central governments and religious authorities of honesty in trade, and ways to fight inequalities born out of commerce. A closer look at these resonating moral codes suggests that while actual market conditions, crises, political and economic turmoil of periods of transition gave rise to variations in the interpretation of pre-modern market morals, prevailing common themes allow for a conceptual comparison.

Keywords: Market inspector, fair trade, just price, hoarding, eparch, commanding good, muhtasib, economic morals, futuwwa, akhi, Medieval Anatolia

This paper scrutinizes medieval Anatolian market inspection by focusing on ideals of justice that plausibly impacted the moral and economic monitoring of urban markets. The preoccupation with justice pertaining to Eastern Mediterranean urban markets can be traced since the "centralization", or rather standardization efforts of political entities from the Bronze Age through Antiquity into medieval times including Persian, Sassanid, Byzantine, Seljuq, Mongol and Ottoman states. Numerous accounts found in the Old and New Testaments, and the Qur'ān reflect ideals of justice pertaining to markets. Although these earliest sources are not our focus here, references to honesty in commerce culminate in the idea that giving the right measure in trade also weighs one's good deeds and bad deeds accurately, paving the way to heaven upon death. Weights and measures were kept in the most significant cathedrals, in a way acknowledging this symbolic link between measuring devices and divine judgement. ${ }^{1}$

* Correspondence details: İklil Selçuk, Associate Professor, Özyeğin University Department of Humanities and Social Sciences. Özyeğin Üniversitesi Çekmeköy Kampüsü Nişantepe Mah. Orman Sk., 34794 Çekmeköy, İstanbul, Office: +902166564987, GSM: +905385462386, www.ozyegin.edu.tr/tr/akademik-kadro/iklilselcuk.

This article is part of the themed section Urban Agencies: Reframing Anatolian and Caucasian Cities (13th-14th Centuries), guest editors: Bruno De Nicola and Matthew Kinloch. To read all related articles, please access: dx.doi. org/10.1553/medievalworlds_no14_2021.

1 For a discussion of balances and weights in the Classical and Hellenistic periods, see Tekin, Balance Weights. I thank Oğuz Tekin for his comments during and after my presentation on Ottoman marketplaces at Koç University's AKMED research center in Antalya on 11 April 2019; Oğuz Tekin, pers. comm., 23 May 2020. For visuals on measuring devices from Antiquity until Ottoman times, see Tekin, Charm of the Market. Storage of weights and measures at the bishops' cathedral was ordered by Emperor Justinian (d. 565) in 545; see Evans, Age of Justinian. For the use of sacred space in the storage of measurement devices in Medieval Europe, see Huitson, Stairway to Heaven, 112. 
Achieving salvation through divine judgement reflects the abstract side of market morals. In practice, governments strove to accomplish the continuity of production, provisions and tax collection by preventing rebellion through keeping productive tax-paying classes unharmed.

Market inspection principles in medieval Anatolia bear similarities to those observed in late antique and Byzantine cities. As these cities had a mercantile class that was comparable to those of Anatolian entities of the thirteenth and fourteenth centuries, their rulers showed similar concerns with economic justice. ${ }^{2}$ These concerns, by and large, were linked to a general understanding that economic exchange in the market created inequalities that needed to be lifted from the shoulders of those who were affected by them, namely the poor and the needy. The issue of economic morality was related to the notion of »trust «; therefore leaders and authorities who imposed rules on urban markets tended to have spiritual legitimacy and a source of charisma based on their spiritual authority in both the Christian and Muslim eras of rule in Anatolia. Morality based on spiritual authority coexisted with the attention to justice paid by rulers who controlled large territories. ${ }^{3}$ Beyond this general semblance, however, different eras present themselves with distinct geographical and ideological specificities, complexities and transformations.

With these varying features in mind, the present study underlines the two facades of market regulation, religious moral teachings on the one hand and the concerns of centralized states on the other. These two facades suggest plausible organic relationships between market regulation institutions, officials, instruments or practices throughout different periods. Rather than detailed accounts and analyses of organic relationships or queries on cultural borrowing, this study will provide a comparison - on the conceptual level - of ideals that seem to have shaped such institutions with probable organic links.

\section{Market Morals under Eastern-Roman Rule}

The late antique Eastern Roman perspective on commerce and market traders was largely influenced by the Church Fathers, whose approach to economic matters was a product of harmonizing Ancient Greek philosophers' (especially Aristotle) concepts of just price, natural exchange and self-sufficiency with Christianity. Converging on the notion that greed is sinful, and commerce results in lying to convince the other party while bargaining, the Fathers encouraged non-economic exchange and free gifts instead. ${ }^{4}$ Turning non-economic exchange into one of the most cherished virtues would result in accumulating wealth in heaven, rather than on earth. ${ }^{5}$ This accord especially defied conspicuous consumption, and encouraged wealth distribution through alms and charity. ${ }^{6}$

2 I thank Claudia Rapp for drawing my attention to this point and for suggestions on related sources. Her comments, and those of others who were present during my presentation of preliminary ideas for this paper at the International Workshop on Urban Agencies on 7 June 2019 in Vienna, are most appreciated. I extend my gratitude to Koray Durak, who read and commented on the final draft of this paper.

3 For the coexistence and mutual exclusivity of rules that supported the governance of large territories and rules that managed local urban markets under the rubric of Islamic Law, see Hodgson, Venture of Islam, 346-348. These views' relevance to the present paper was formulated in light of Huricihan İslamoğlu's work on global history studies and our discussions with her. Huricihan İslamoğlu, pers. comm., 7 November 2019.

4 Laiou, Trade, profit and salvation, 247.

5 Angeliki Laiou puts patristic teachings into perspective, underlining their continuous emphasis on the input of labor, which provided legitimacy to production according to the principle of autarky, and their support for charity in the early period, when commercial activities of merchants were suspected of deceit. Laiou, Trade, profit and salvation, 246.

6 Laiou, Trade, profit and salvation, 263-264. 
During the Roman era, the collection of urban taxes and market inspection were the responsibility of curiales (city councils), from whom urban officials were elected. ${ }^{7}$ With Late Antiquity, however, an winternal structuring " of the city councils took place when state bureaucrats were sent to prevent local injustices committed by provincial governors and autonomous curiales. In this context, the office of defensor civitatis, a previously existing one that had been neglected for some time, was resurrected during Justinian's reign (527-565) to fight against injustice. ${ }^{8}$ As Justinian's reform efforts increased the authority of defensor civitatis, they coincided with a transformation in the duties of bishops which expected them to partake in municipal administration. ${ }^{9}$ Bishops' participation in civic self-governance was a sign of the recognition of their spiritual and ecclesiastical leadership. ${ }^{10}$ In Claudia Rapp's words, this development signaled the birth of the "career bishop «. ${ }^{11}$

As career bishops assumed their duties in cities such as Alexandria, Pelusium, Antioch, and Constantinople, they became closely involved in market affairs, and dealt with poverty and income inequalities, drawing upon Christian ideas of wealth distribution, deciding on which category of income or commercial activity was tolerable, acceptable, or sanctioned. ${ }^{12}$ Their responses generally sought to resolve problems of household management (oikonomia), determining legitimate income and acclaimed use of surplus capital, admonishing conspicuous consumption, and differentiating self-interested economic ambitions from altruistic ones. ${ }^{13}$ As household management and redistribution of economic resources potentially involved neglect or exploitation of the poor, the teachings of Jesus Christ suggested "generalized reciprocity", and the "Pauline work ethic«, highlighting self-sufficiency (virtuous autarkeia). ${ }^{14}$ While hoarding was perceived as irrational and immoral, it further related to Graeco-Roman perceptions of the rural and the urban as the two contradicting sides of "natural and the artificial « ways of life. ${ }^{15}$

8 Frakes hypothesizes that the office was created before 319. Frakes, Origin of the defensor civitatis. 347-48. In his later work the author suggests that the office underwent a reform during the reign of Valentinian I (364-375); Frakes, The Syrio-Roman lawbook, Byzantion, 353-355. The later revival of the office by Justinian expanded the duties of defensor civitatis by entrusting the official with minor criminal cases, and brought a system of rotation in appointment. See Bury, Later Roman Empire, vol. 1, 6o-61, 443; vol. 2, 336, 362.

9 Rapp, Holy Bishops, 288.

10 Rapp, Holy Bishops, 289-290.

11 Rapp, Holy Bishops, 302. A critical moment during the surrender of Egypt to the Muslims (641) is reflective of the extent of responsibilities handed to these bishops. John of Nikiu's chronicle reveals that Cyrus, the bishop of Alexandria (d. 642), undertook the task of negotiating the terms of peace with the Muslims. John of Nikiu, The Chronicle, 120, trans., Charles, 22-27.

12 Merianes and Gotsis, Managing Financial Resources, 1.

13 On the co-occurrence of self-interested pursuits with charity, see Merianes and Gotsis, Managing Financial Resources, 8; 17.

14 Merianes and Gotsis, Managing Financial Resources, 18, 22, 24-26.

15 Merianes and Gotsis, Managing Financial Resources, 28. 
Basil of Caesarea (d. c. 379), Gregory of Nyssa (d. after 394), Gregory of Nazianzus (d. c. 390) and John Chrysostom (d. 407) are some prominent representatives of patristic economic ideas. ${ }^{16}$ These bishops censured self-indulgent capital accumulation and supported the use of personal wealth toward self-sufficiency and charity, promoting almsgiving both as the manifestation of selfless and impartial love and as a practical solution to inequality. ${ }^{17}$ Basil and Gregory of Nazianzus condemned large landowners who turned to hoarding to make more money, causing further shortages in grain supply. Basil's warning against such practices culminated in his oration on food shortage in Caesarea, partly caused by famine (368369) and partly by profit-seeking hoarders, whom he addressed, saying, "Look now how the multitude of our sins forced the seasons to [be] unnatural. $\aleph^{18}$ In his oration, Basil aimed at inducing the hoarders to either sell their product or give it away to those in need (Hom. 8), as they were not the owners but only the custodians of resources granted by God (Hom. 6). As a practical solution to inequality, Basil - hence the term Basileias - built a complex named ptochotropheion, providing lodging for passers-by, a poorhouse for the needy and a hospital, outside the walls of Caesarea. This complex also provided sustainable employment opportunities for the needy. ${ }^{19}$ John Chrysostom (d. 407) lived in Antioch and, as bishop in Constantinople, sanctioned almsgiving for equitable wealth distribution instead of hoarding. According to Chrysostom, almsgiving is an exchange of "money for grace « that cancels debts from sin, and must be offered as one-tenth of income to the poor. ${ }^{20}$ Like hoarding, usury was condemned in Christian teachings. In tune with Aristotle's view, while Gregory of Nyssa regarded interest as "unnatural income" from inanimate sources, gained without productive labor, Chrysostom prescribed self-sufficiency, whereby one tries to get out of financial stress by one's own means in times of need. ${ }^{21}$

Along with prescriptive patristic teachings, hagiographies also include accounts of the relationship of spiritual authorities, especially saints, to market activities. The life of St. Symeon Stylites the Younger (d. 592) reveals that his father's family had moved from Edessa to Antioch as professional perfume dealers. When the Saint was offered Indian sandalwood by a prominent Syrian dealer, he put the product to the test by burning it, which revealed a foul smell. This coarse odor, the Saint concluded, indicated the indecency of the dealer's deeds. ${ }^{22}$

Rapp, Holy Bishops, 181 and 185; Kelly, Golden Mouth, 4-5; Mayer and Allen, John Chrysostom, 5.

Merianes and Gotsis, Managing Financial Resources, 73, 60.

18 Basil, Hom 8.4., PG 31, 308.

19 Merianes and Gotsis, Managing Financial Resources, 79-82. Houses for the poor (ptocheia) constituted valued projects of the Church led by bishops in Antioch and Alexandria. Additional ones were built in Amasea of the Pontus eparchy. Byzantine emperors, on the other hand, were equally concerned with and took part in philanthropic missions to look after the poor. Until the twelfth century, numerous ptocheion were built in Anatolian lands, including those in Perga, Magnesia, Nicaea and Prousa. See Constantelos, Byzantine Philanthropy, 257-269.

20 Merianes and Gotsis, Managing Financial Resources, 92-94. On Chrysostom's positive attitudes towards taking care of the poor and the voluntary poor, see Mayer, Poverty and generosity, 158 .

21 Merianes and Gotsis, Managing Financial Resources, 96-98.

22 Magouilas, The lives of saints, 306. 
Several relevant incidents from the life of St. John the Almsgiver (d. 616) are narrated by Leontios of Neopolis (seventh century) ${ }^{23}$ Leontios recounts the patriarch's effort to impose standard weights and measures in the market. For this purpose, he sends his »treasurers and ushers " around the town and orders that all weights and measures must be uniform. What is noteworthy is the fact that the punishment for not abiding by the rules for the intruder is to transfer his possessions to the poor. In other words, the transfer of wealth to the needy is enforced by Saint John the Almsgiver as a form of punishment for unjust behavior in the urban market. ${ }^{24}$

While lives of saints and theological or legal prescriptive texts included ideals of justice and equity, everyday lawful contractual transactions in the market readily pushed their boundaries. Particularly throughout periods of economic hardship, regulations extoled a just price, just value, and just profits. As the urban marketplace was the center of the "unnatural« way of life that facilitated accumulation, conspicuous consumption and hoarding, it was perceived as a location where evil manifested itself. Brigitte Pitarakis illustrates »indicators of evil« at the market of Constantinople, which included cheating in commercial transactions, the spoilage of food and drink, and natural disasters. A peculiar combination of faith and magic was believed to provide protection against such hazards. This combination was attained through various means, including writing prayers and protective talismans, or lucky charm stamps attached to market merchandise. ${ }^{25}$ The negative side of magical involvement in market affairs was the use of spells in order to inflict harm on rival businesses. ${ }^{26}$ Hagiographies relate exorcisms performed by Symeon the Fool (sixth century) and Basil the Younger (tenth century) at Constantinople's markets to get rid of the involvement of evil in economic transactions, or for blessing honesty in business. ${ }^{27}$

Constantinople's monuments were also perceived as protectors of economic activities in the market. Chronicles testify to the existence of two bronze hands above the bronze grain measure (modios) to warn potential tricksters that this would result in having their hand chopped off, an appropriate punishment for fraud..$^{28}$ Similarly, a pair of statues known as the Just Judges at the Philadelphion "settled disputes" on commodity prices. As coins were placed in the hand of one of the statues, it was understood that the just price was attained when additional coins were rejected. ${ }^{29}$

Hagiographies reflect a gradual transformation in the perceptions of profit-making commercial activities. Departing from the strict interpretations of early patristic teachings, Nikephoros, the ninth-century patriarch of Constantinople (806-815) dictated a profit margin of ten percent, embracing the idea that the risk taken and the labor exerted by merchants entitled them to a maximum rate of ten percent in profits without entering the "unreasonable« realm. ${ }^{30}$ By the tenth century, commercial gain by the merchant becomes acceptable..$^{31}$ 
"Dirty money« is then associated with large amounts of wealth concentrated in the hands of individuals who were mostly public officials such as tax collectors or fiscal agents, for they accumulate money by oppressing the poor. Commercial activity, on the other hand, deserves remuneration, as it requires effort and labor on the part of the merchant. ${ }^{32}$ Praise for the diligent and profit-seeking merchant due to his labor is, in Laiou's words, »the middle Byzantine answer to the questions regarding trade, mercantile activity, profit, and salvation «. ${ }^{33}$

Since the period that followed Justinian's law, Byzantine craftsmen and urban producers were organized in corporations and were subject to the eparch of Constantinople. ${ }^{34}$ The tenth-century Book of the Eparch provides information about this office that was responsible for maintaining fair trade, just prices, just value, acceptable profit margins, and unadulterated weights and measures. ${ }^{35}$ While guilds' proximity to public interests determined their control either directly by the eparch or by his auxiliaries, these officials searched for forbidden acts, including tricking customers by using rigged weighing devices and by selling fraudulent manufactured goods, participating in more than one trade, pilfering the employee of another tradesman, and hoarding necessities for excessive profits. ${ }^{36}$ The Book of the Eparch of the market of Constantinople is not comprehensive in the branches of crafts and trades to which it refers. ${ }^{37}$ It is confined to major commercial activities concerning fiscal and financial transactions such as goldsmiths, bankers and notaries. It refers to producers and merchants of profitable trades such as the production and sale of silk textiles, and the spice trade. Everyday necessities produced by saddlers, soap makers, fishmongers, innkeepers, butchers, sheep sellers, and chandlers were supposed to be closely scrutinized by the eparch. ${ }^{8}$ Prices in the market of Constantinople were attained via a combination of principles of justice and market conditions as the Book refers to "unreasonable profit, « and lays down »just profit« margins accordingly. In addition to limits placed on prices in order to control profit levels, the principle of enormous damage (laesio enormis) was widely used to prevent wages from plunging below "just « wage levels. Through the tenth to twelfth centuries, policies of government had relative success in limiting market transactions around the aforementioned principles of justice. ${ }^{39}$ In the case of Constantinople, market regulation was as much a matter of provisioning of the palace and the capital as implementing rules of moral conduct in commerce.

These principles of justice prescribed acceptable or sanctioned ways of managing surplus wealth by divestment or redistribution, through almsgiving, ptōchotropheion, or support for monasteries or for particular church factions, in return for the prospect of salvation. These practices were coupled with an emphasis on honesty in trade in the markets through the proper use of weights and measures and condemnation of profiteering, usury, conspicuous

The latest edition and translation of the tex

Dujčev. For further analyses of the Book of the Ep Maniatis, Organization; and idem, Domain of private guilds.

36 Laiou and Morrison, Byzantine Economy, 72.

37 Maniatis, Domain of private guilds, 344.

38 Maniatis, Domain of private guilds, 72.

39 Laiou and Morrison, Byzantine Economy, 62. 
consumption, and hoarding. Savings were accepted so long as they supported self-sufficiency, and surplus wealth was directed toward beneficence to ensure social justice and equity. Social justice and equity were of concern to the state in so far as they related to the continuity of production, taxation and provisioning. Hagiographies of saints' lives gradually change their tone towards the market and merchants over time, and start displaying positive views about them from the eleventh century onward. Commercial exchange and respect for contracts increasingly becomes legitimate in the eyes of the spiritual authorities. Merchants are no longer considered to be oppressors of the poor, at least, not any more than government officials. ${ }^{40}$ Wealth management in the late antique Christian and Graeco-Roman world was guided by the spiritual authority of patristic teachings, saints and bishops of the early period. Despite the effects of socio-economic transformations on these ideas of justice in varying degrees over time, comparable market morals resonated throughout Byzantine history.

\section{Market Morals under Muslim Rule}

More than a few parallels exist between the ideals and institutions that induced proper standards in Byzantine markets and those under Muslim rule in Anatolia, such as the Islamic charitable endowment (waqf), a sound instrument in the fight against poverty while serving pious ideals. ${ }^{41}$ Market inspection in the Islamicate world was largely based on the Qur'anic injunction of "commanding the known or acceptable practices, and prohibiting the wrong or morally outrageous ones « commonly referred to in Arabic as the duty of hisba. ${ }^{42}$ The injunction, henceforth commanding good, is the universal claim for all prophetic premises in its broadest sense. In lands under Muslim rule the duty of commanding good was overseen by an official called muhtasib, whose operations resembled the Greek agronomos, Byzantine eparch, and Iberian el señor del zoco, zobozoque (sāhib al-sūq) and almotaçen. ${ }^{43}$ Market rules in medieval Anatolia were applied with the participation and the agency of individuals and various interest groups such as urban craftsmen, notables, and akhi brotherhoods, who are thought to have functioned as spiritual, chivalric, and professional figures. Akhi brotherhoods' moral foundation was futuwwa (T. fütüvvet) ethics - codes of conduct that guided urban craftsmen, which markedly overlapped with commanding good, as will be discussed further. ${ }^{44}$ Organic relationships between corresponding functionaries from different periods and the possibility of "cultural borrowing « have been underlined by several scholars. ${ }^{45}$ While the present study does not delve into the problem of "origins", the rest of the paper will make occasional references to parallel institutions from distinct eras.

40 Contempt toward merchants, in Laiou's words, was an aristocratic attitude and therefore coincided with periods of aristocratic strength, namely up to the sixth century and after the eleventh. Laiou, Trade, profit and salvation, 261-263.

41 For a comparison of Byzantine and Seljuq pious foundations, see Yıldırım, Pious foundations. On charitable institutions, see also Singer, Charity in Islamic Societies; Singer et al., (eds.), Feeding People.

42 The translation of the Qur'anic injunction of "al-amr bi'l-ma'rüfwa'n-nahy 'ani'l-munkar« is by Engin Akarl.

43 Foster, Agoranomos and Muhtasib; Glick, Muhtasib and Mustasaf; idem, New perspectives.

44 For a recent discussion of the fütüvvet literature, see Peacock, Mongol Anatolia, 117-144.

45 Among numerous others, on the possible pre-Islamic origins of the office of the muhtasib, see Crone, Roman, Provincial and Islamic Law, 108. For a criticism of Crone's views on continuity or borrowing, see Hallaq, Use and abuse. 


\section{Commanding good}

The official appointed to command good and to collect the relevant taxes in markets under Muslim rule stood within coexisting multiple jurisdictions, including those of the judge, the police, and the court of complaints. ${ }^{46}$ The duties of the official theoretically fell within one of the realms concerning the rights of God, the rights of the people, and a combination of both. ${ }^{47}$ In practice, however, mundane and religious duties were immediately discernable. The former included checking the quality, weight and measure of goods sold by craftsmen and retailers in the urban market; preventing hoarding and speculation; and punishing wrong behavior. Moral or religious duties, on the other hand, comprised maintaining order in public places by segregating men and women; ensuring congregational performance of the Friday prayer; checking fasting during Ramadan; watching itinerant sellers and shop deliverers during their encounters with private households; checking alcohol consumption by Muslims; public alcohol consumption by non-Muslim people of the Book under the protection of Muslim rule; and making sure that they followed clothing regulations. Public places other than the market were bathhouses, the cemetery and brothels, where mourners, prostitutes, storytellers, merchants, builders, the people and the public/private intermingled..$^{4}$ Wealthy merchants who worked with brokers and agents in their headquarters hardly ever fell under the jurisdiction of the market inspector. The muhtasib received help from experts in the crafts, who guided him or stood in for him when needed. His booth was situated in a central location of the market. Adulteration, speculation (especially in grain and other basic necessities), hoarding, profiteering and price infringements were punished directly by the market inspector without a hearing in the court of the judge, unless the official decided otherwise. Punishments often involved fines, beating with a cane, or much less frequently, exemplary justice in the form of ignominious parading. ${ }^{49}$

While giving the right to maintain social order to the rulers, the aforementioned Qur'anic injunction, found, among other places, in the chapter of Âl-i Imran, also paves the way for individuals to assume this role in the society: "And let there be [arising] from you a nation inviting to [all that is] good, enjoining what is right and forbidding what is wrong, and those will be the successful. $\aleph^{50}$ Doctrinal variations among the major schools of Sunni Islamic Law ${ }^{51}$ generate debates on who is truly entitled to enforce this mechanism, whether or not coercion and weapons must be allowed and whether or not the permission of the ruler is necessary, who is authorized to apply the rules with their hands, and who is only authorized to impose the duty "with their tongue«. ${ }^{2}$

46 Lange, Overlapping jurisdictions, 85-107.

47 "Enforcement of the right includes the three parts: enforcement of what is due to God, of what is due to man and of what is due to both jointly."Ibn al-Ukhuwwa, Ma älim al-qurba 2, ed. Levy, 34 .

48 For discussions of the concepts of public and private in Islam, see Mottahedeh and Stilt, Public and private, 735748 and Klein, Between public and private, 41-62.

49 On punishments, see Lange, Ignominious parading (tashhir), 81-108 and Lange, Justice, Punishment, 57-60.

50 The Qur'ān, Surah Âl-i Imrān III:104.

51 Mãlikì, Hanbalì, Shäfì and Hanafì. See: Hallaq, Islamic Law.

52 Cook, Commanding Right, 470-479. 
In addition to the Qur'an,,$^{53}$ references to commanding good are found in prophetic traditions,$^{54}$ in books and chapters in works by prominent scholars of Islamic Law such as Al-Māwardī (d. 1058), Al-Ghazālī (d. 1111), and Ibn Taymiyyah (d. 1328). More specifically, handbooks or legal and prescriptive manuals were produced to guide market inspectors. Among these handbooks, those authored by Al-Shayzari (d. 1193), Ibn al-Ukhuwwa (d. 1329), and Ibn Bassām (d. c. 1440) are widely cited. Beside these works, chronicles, biographical dictionaries, works on weights and measures, general pamphlets on moral issues, appointment deeds of market inspectors, price lists and legal compilations are available. Prescriptive manuals produced by scholars like al-Shayzari and Ibn al-Ukhuwwa provided the framework for these generally known practices of market inspectors. The ideal muhtasib portrayed by these texts was a good Muslim of integrity with a fair amount of knowledge of Islamic Law. ${ }^{55}$ Al-Shayzari's Book of the Islamic Inspector based on the author's observations of twelfth-century Syrian towns is significant for its wide circulation in Eastern Mediterranean Islamicate lands as a model text for later guides. ${ }^{56} \mathrm{Ibn}$ al-Ukhuwwa's work on the market inspector is largely built on al-Shayzari's text, with a wider content with the additions of artisans and different legal opinions. ${ }^{57}$

Al-Shayzarì's manual deserves a closer look, as it provides a practical and comprehensive guide for the market inspector. The text predicates a balanced concern for moral/religious duties and mundane commercial duties of the market inspector from how to treat beasts of burden to segregation of the sexes $;^{58}$ from checking the accuracy of weights and measures ${ }^{59}$ to the provision of necessities; ${ }^{60}$ from common tricks used by producers and sellers to hygiene and the morality of health professionals, and the integrity of male and female slaves. ${ }^{61}$ Besides these chapters, two separate sections of al-Shayzari’s manual are noticeably particularized. While one of them is reserved for moral and religious issues involving public good, ${ }^{62}$ a separate section is dedicated to proper commercial conduct and a description of lawful market transactions. The latter, which is of specific interest for the present study provides a list of impermissible acts, including collusion (to offer a high price for a commodity not for the purpose of buying it but rather to tempt someone else into purchasing it); »sale against a brother's sale " (to buy something at a fixed price when one can return it, and someone else's offer of another commodity knowing that the person can return it); »offering a commodity

53 Such as (Sūrah al-Hūd, XI, 85): »Hence, o my people, [always] give full measure and weight, with equity, and do not deprive people of what is rightfully theirs, and do not act wickedly on earth by spreading corruption."

54 Hadith: "a transmitted report of the Prophet's normative practice (by saying, action, or acquiescence)« which constitute the Prophetic sunna, collectively. Stilt, Islamic Law in Action, 211.

55 Al-Shayzarĩ describes the ideal muhtasib as someone with knowledge of Islamic Law in order to know what to order and what to forbid. Al-Shayzarī, Nihāyat al-rutba, trans. Buckley, 28-32. According to Ibn al-Ukhuwwa, he must be "sturdy in the faith, and acquainted with the provisions of the law, seeing that nothing is good or bad save what the law declares to be so.«Ibn al-Ukhuwwa, Ma'âlim al-qurba 1, ed. Levy, 14-15.

56 Stilt, Islamic Law in Action, 58.

57 Stilt, Islamic Law in Action, 59-60.

58 Al-Shayzarī, Nihāyat al-rutba, trans. Buckley, 38-39.

59 Al-Shayzarī, Nihāyat al-rutba, trans. Buckley, 45.

60 Al-Shayzarī, Nihāyat al-rutba, trans. Buckley, 46.

61 Al-Shayzarī, Nihāyat al-rutba, trans. Buckley, 103.

62 Al-Shayzarī, Nihāyat al-rutba, trans. Buckley, 124-135. 
for sale against their brother's offer " (to offer a better commodity for the price someone has paid, or to offer a similar one for a lower price); selling a commodity after an unspecified period, or selling it with a payment upon an unspecified future event; buying something from a merchant and selling it to another person before even getting a hold of it; selling by "touch" (to say »if you touch the item of clothing, you will have to buy it«); buying a commodity at a stated price, but reducing the price once the transaction is concluded; cooperating with other sellers or the market crier to buy merchandize at higher prices to raise the market value. ${ }^{63}$ In addition to these unlawful transactions, money changers are warned against usury, to keep away from deeds against the religion. Selling gold for gold, or silver for silver in the same amounts was forbidden since it implied that the person made profit from money. ${ }^{64}$ The market inspector was not to fix prices in the market; he was to prevent hoarding, monopolies, and meeting caravans (to trade) before they entered cities.

Hoarding is generally accepted as a forbidden act, and is mentioned both by al-Shayzari and Ibn al-Ukhuwwa. The latter states, »A person who has hoarded foodstuffs in time of scarcity and waits only for an opportunity in order to sell, must be compelled by the muhtasib to sell his stock, for hoarding is forbidden and the hoarder accursed.« ${ }^{65}$ Traditions of the prophet cited in relation to hoarding are: "The one who brings food to the market is blessed, and the one who hoards it is cursed; ${ }^{26}$ and "Whoever hoards food for forty days, then gives its value as a charitable gift, the gift does not serve as atonement for hoarding. ${ }^{67}$

Unlike the position of scholars towards hoarding, the issue of price fixing is more problematic. A tradition of Prophet Muhammed on price fixing relates that when asked to fix the prices in the market of Medina, he refused to do so, saying, "Only God establishes the prices, and I want to meet God without anyone claiming restitution from me because of an injustice I committed to person or property. ${ }^{68} \mathrm{~A}$ liberal price regime was generally supported by Muslim jurists. Price-ceilings were only allowed in cases of famine or dearth, in order to prevent hoarding, which was clearly forbidden due to its harm to the community of believers. Therefore, breaking the principle of free market prices was only legitimized based on the concept of public good (maslaha). An official announcement of dearth by the judge was necessary for the implementation of price fixing. According to prevailing circumstances, hoarders could be forced to sell their stocks at the market price or at a fixed price imposed by the authorities. ${ }^{69}$

Apart from the aforementioned market-inspection manuals that were widely circulated, there is scant evidence on the rules that guided the Anatolian market inspector that predates the mid-fifteenth century. Anatolia was loosely centralized under Seljuq rule before it underwent Mongol suzerainty (1243). From Seljuq to Mongol and beylik (post-Seljuq principalities) periods, urban commercial activity nevertheless continued within an ever-shifting web

63 Al-Shayzarī, Nihāyat al-rutba, trans. Buckley, 81-83.

64 Al-Shayzarī, Nihāyat al-rutba, trans. Buckley, 96.

65 Ibn al-Ukhuwwa, Ma'älim al-qurba 89, ed. Levy, 21.

66 Ibn Māja, Sunan Ibn Māja 2, ed. Fuad, 728 (hadìth 2153); Stilt, Islamic Law in Action, 153-154.

67 Ibn al-Ukhuwwa, Ma'âlim al-qurba, ed. Levy, 65-66.

68 Abū Dāwūd, Sunan Abī Dāwūd 5, ed. al-Arnāuṭ and Qarahbalalī, 320-321 (tradition 3450); Ibn Māja, Sunan Ibn Māja 2, ed. Fuad, 741-742 (tradition 2200); al-Tirmidhī, al- Jāmíal-Kabìr 2, ed. Ma'rūf, 582 (tradition: 1314). On the topic of regulating prices, see Sabra, »Prices Are in God's Hands«; Kallek, Narh; Kütükoğlu, Narkh.

69 For the illustration of the imposition of the rules in Mamlūk Egypt, see Stilt, Islamic Law in Action, 154-174. 
of political and economic alliances. Moreover, there is considerable variation between what is described by prescriptive treatises of economic morals and actual market practices throughout centuries, geographies, specific locations, dynasties and individual market inspectors from different backgrounds. The moral economy was never reducible to the real economy. It was not totally unrealistic, yet it extended beyond what was applied in the market. ${ }^{70}$

Several up-to date studies that employ narrative, art historical, architectural and archeological sources provide fresh insight into medieval Anatolian cultural and commercial life. ${ }^{71}$ The period is characterized by the prominent caravanserai network constructed by the Rum Seljuqs prior to the arrival of the Mongols, which connected the region to Iran, the Silk Road, the Black Sea and the Mediterranean. Understanding the post-Mongol period, however, as suggested by Sara Nur Yıldız, requires a deeper grasp of the economic, artisanal and intellectual interaction of local agricultural and urban communities with their pastoralist overlords. ${ }^{72}$ The shifting of Anatolian trade routes in the 1300s due to competition among the Ilkhanid, Mamluk, Byzantine, the Golden Horde, Venetian and Genoese powers was also the scene for the imposition of the Ilkhanid economic policy of monetization and currency standardization by Ghazan Khan (r. 1295-1304)..$^{73}$ The success of such policies may be uncertain; however, each of these developments would have repercussions on urban markets and their regulation.

In the Rum Seljuq period, a council of urban inspection (divān-i muhtasib) is mentioned in an order concerning market rules. ${ }^{74}$ The market inspector in this organization was appointed by royal decree and paid out of the fees collected from craftsmen and retailers of the market by way of tax-farming. His duties of facilitating commerce, watching over non-Muslims; checking craftsmen, measures and scales; and making sure that transaction rules were correctly implemented, focus on market affairs. A market inspector's appointment decree from fourteenth-century Sivas reveals that he was also expected to assume the duty of disciplining those who departed from the path of God..$^{75}$ One of the conspicuous ways in which such departure occurred involved the consumption of alcoholic beverages by Muslims. Trépanier's detailed analysis of available sources on central Anatolia suggests that alcohol consumption was observed among the elites of political and military circles. Ordinary Anatolians, some sources reflect, stocked up on (grape and pomegranate) wine before winter set in. ${ }^{76}$

70 "Reputation« was a significant part of the market, and it depended on debt and paying the debt. The relations between wholesalers and retailers were also credit/trust relations related to debt.

71 Izdebski, Jaworski, Üstündağ, Sołtysiak, Bread and class, 335-357; Goshgarian, Diversity in the Medieval Middle East, 140-158; Melville, Anatolia under the Mongols, 51-101; De Nicola, Letters from Mongol Anatolia, 1-14; De Nicola, On the outskirts of the Ilkhanate, 117-135; Ylldı, Mongol Rule, 388-414; Yıldız, Post-Mongol pastoral polities, 27-48; Trépanier, Foodways and Daily Life; Blessing, Rebuilding Anatolia, 165-203.

72 Ylldız, Post-Mongol pastoral polities, 42.

73 Blessing, Rebuilding Anatolia, 165-166. The encyclopedic work, Masalik al-Absar, by a Damascene-Mamluk official Ibn Fạ̣l Allāh al-'Umarī (1301-1349), provides a picture of non-standard prices and currencies in Anatolia. On al-'Umarī's contribution to Anatolian historiography, see Trépanier, 141.

74 The head of the council was called the head of the council of rules pertaining to the order of commanding good (hākim-i dìvān-ı hisba). Konevî, Tekārīrü'l-Menāsııb, ed. Turan, 43-44.

75 Khū'ì, , Gunyetü'l-Kātib, ed. Erzi, 33-34.

76 Trépanier, 118. 
An early fifteenth-century manual of epistolography is noteworthy as it contains the oldest-known official records written in Turkish in Anatolia. ${ }^{77}$ The appointment deed of the market inspector of Ladik (Denizli) found in this collection enlists his duties as follows:

1. To command good and forbid wrong; to discipline and threaten those who drink and depart from the right way;

2. To announce the prices of drinks, foodstuffs, clothing and grain among the people of the market; ${ }^{78}$

3. To watch over the scales and measures used;

4. To inspect grocers, (bread) bakers, sheep's-head cooks, halwa (sweet) confectioners and other artisans once a month;

5. If narkh is discovered to be short, to take a fine of 1 asper/dirhem; to punish each group of craftsmen according to their deeds; not to favor anyone, and to execute the necessities of market rules. ${ }^{79}$

In the contemporaneous appointment deed from Konya, while the beginning is verbatim the same as the above-cited deed of investiture, the following is added:

1. This one must continue the previous market inspectors' practices.

2. Under no condition will the orders be infringed or interfered in.

3. Must oversee the prayer for the continuation of the realm. ${ }^{80}$

Available sources suggest that Rum Seljuq muhtasib's obligations were almost limited to commercial or market affairs. This is in contrast to the detailed account that embraced religious and mundane duties found in al-Shayzari's manual. The focus on commercial duties in the Seljuq and Ottoman deeds of investiture overlap, ${ }^{81}$ which brings us to the question of what was expected from an early-Ottoman market inspector.

Our knowledge of early-Ottoman policies is based on fifteenth-century chronicles written retrospectively, when humble, redistributive economic perceptions and the refusal to tax the people of the market had already changed into the fiscalist measures of the central Ottoman state. ${ }^{82}$ According to Cemal Kafadar, influences that embodied the concepts of just price, fair trade, the circle of justice, the quadripartite society ${ }^{83}$ and household management (oikonomos translated into Ottoman via Arabic as tadbir al-manzil) entered the Ottoman court in

77 The scribe is thought to have served in the court of the Germiyanid principality (1302-1428). Kirımlu Hafiz Hüsam, Teressül, trans. Tekin.

78 The said prices are the maximum prices (narkh) allowed by the authorities.

79 Narkh, in this case, refers to the proper weight, rather than the price of commodities.

80 "He must strongly hold on to the prayers for the continuation of the state, and anticipate the increase of blessings." Trans. mine.

81 In a comparison of four market inspector appointment diplomas from Great Seljuq, Rum Seljuq, Khwarazmshāh, and Ottoman periods, Richard Wittmann observes that the Rum Seljuq document, which sets out the duties of the market inspector of Konya, devotes all except one clause to market-related activities. Moreover, the market inspector of Konya was to hold the office as a tax farm (muqäta'a) in line with the later Ottoman practice. Wittmann, Muhtasib in Seljuq Times, 108-128.

82 Kafadar, When Coins, 22.

83 The division of society by the Persian philosopher and theologian Nașī al-Dīn al-Ṭūsī (d. 1274) as men of the pen, men of the sword, men of agriculture, and of commerce in his Akhläq-e Näșiri (13th century). For the influence of this division in Ottoman political thought, see Sariyannis, Ottoman Political Thought, 92. 
the fifteenth century. ${ }^{84}$ Geographical overlap, local knowledge to which the Ottomans had access upon their rule over Bythinia prior to the fall of Constantinople and, following the Ottoman conquest, similar concerns with provisioning of the capital city deserve further attention pertaining to parallels in Ottoman and Byzantine market administration regimes. ${ }^{85}$

Among the few sources that could be used for such a comparison, the aforementioned Book of the Eparch was a legislative text with limited objectives. Notaries; money changers; manufacturers of high-value products such as goldsmiths, silk textile weavers and merchants; trades prone to fraud; those who were imperially commissioned; and, in particular, trades that provided the people of the capital fell under the jurisdiction of the eparch of Constantinople. ${ }^{86}$ Alternative networks and small traders were excluded from the Book of the Eparch because they had a limited number of members and small turnover; they did not involve an extensive division of labor; they sold their products themselves, or with middlemen so they would not act together to exploit consumers; the commodities they produced did not involve prohibited items; and their "dealings and infractions « were the subjects of common law. Therefore, strict supervision and governmental control were deemed unnecessary. ${ }^{87}$ Provisioning Byzantine Constantinople and Ottoman Istanbul, albeit in distinct periods and contexts, had common objectives of provisioning the respective imperial capitals that lay in the same geographical location, sustained by a corresponding hinterland. Ottoman market regulation ideals and policies of the later period are documented in detail by sultanic law codes (qänünnāma) and sources on the office of palace purchases (hasssa kharc amini) of Bursa, who was responsible for providing the Topkapı Palace of Istanbul with fresh produce from the fertile Bursa gardens. ${ }^{88}$

\section{Fütüvvet Morals}

As the injunction of commanding good guided Muslim rulers of Anatolia in the realm of market regulation, an equally noteworthy moral tradition known as futuwwa (henceforward T. fütüvvet) gained esteem in twelfth-century Anatolia. ${ }^{89}$ A closer look at fütüvvet literature reveals that while influencing ceremonial functions of artisanal young men's (fityān) organizations, it prescribed charity, renunciation of voracity and greediness, and following "legitimate" ways of income generation to avoid poverty. As fütüvvet was embraced by urban spiritual, chivalric and professional brotherhoods called akhis in Anatolia, it impacted perceptions of proper moral conduct in urban settings. ${ }^{90}$ The waning of Ilkhanid

84 Kafadar, When Coins, 35-36.

85 Due to provisionist concerns, price regulations of necessities, especially of grain, were implemented by Ottomans, as they were in similar circumstances by Byzantine policies, or as demonstrated by Seven Ağır, in Iberia. See Ağır, From Welfare to Wealth. See also Magdalino, Studies IX, 35-47. For comparison and continuity between Byzantine and Ottoman commercial practices in relation to the topography of the capital, see Mango, Commercial map of Constantinople, 204-207; İnalcık, Hub of the city.

86 On the Book of the Eparch and the Byzantine urban economy, see Gilbert Dagron, The urban economy, 407. See also Idem, The domain of private guilds, 339-369.

87 Maniatis, Organization, 344.

88 Ottoman market regulation is outside the scope of the present study. For my analysis on the subject, see Selçuk, Ottoman market-regulation. On the office of palace purchases, see Selçuk, Osmanlı şehir ekonomisi.

89 It was the Abbasid caliph al-Nāṣır al-Dīn Allāh (d. 1225) who admitted futuwwa into his court, and invited the Rum Seljuq sultanate to join futuwwa by sending a prestigious emissary and gifts.

90 Particularly following the defeat of Seljuqs of Rum by the Mongols (1243 Kösedağ Battle), as the prominence of akhis increased in Anatolia. 
power and control over Anatolia as of the 1330s resulted in the "localization " of patronage and endowments by communities of Sufis and akhis in the smaller, but nevertheless significant centers of Ankara, Amasya and Tokat. ${ }^{91}$ The Arslanhane complex is a striking example of rare survivals showing the influence of akhi brotherhoods in fourteenthcentury Ankara. Their ties to fütüvvet morals and urban professions, their distinction from Sufi circles and their presumed chivalric qualities characterize akhis as a manifest group of the transition period between Seljuq, Mongol and post-Mongol periods of Anatolia. ${ }^{92}$

While fütüvvet is widely accepted as an Islamic genre, Christians also subscribed to similar organizations, as shown by an inscription that mentions a Greek $a k h \bar{\imath},{ }^{93}$ and Armenian manuscripts written in the fütüvvet genre to guide brotherhoods around similar moral codes. ${ }^{94}$ Earlier works by Speros Vryonis drew attention to the similarity between institutions such as Roman demes, Byzantine circus factions, youth associations (neaniai) and panegyris with those of the Islamic East, including futuwwa, fityān, ahdäth, and panair, suggesting basic affinity and even probable common ancestry. ${ }^{95} \mathrm{~A}$ much broader view of influences on urban Anatolia necessitates accounting for Iranian influences prior to the arrival of the Mongols. Carole Hillenbrand underlines twelfth-century Persian influence on the Seljuq court, especially regarding the Seljuq patronage of Muhammad b. 'Alī Rāvandī as a counterweight to lasting Byzantine impact. ${ }^{96}$

Recent studies that provide novel insight into medieval Anatolia in a considerably nuanced picture feature complexity. Rachel Goshgarian's studies show that fütüvvet texts produced in the lands of Rum by Christians and Muslims interacted with each other, a phenomenon that was probably bolstered by a striving for reform by the Armenian Church, vis-à-vis the challenge posed by Islamic institutions. ${ }^{97}$ The thirteenth and fourteenth centuries are described by the author as "a time of cultural, geographical, and political in-betweenness « $"{ }^{98}$ which manifested itself in the form of architectural and textual hybridity of comingling, fluid identities, specifically observed in urban settings. ${ }^{99}$ Associations around fütüvvet-like ethics among Muslims and Christians reflect a common influence by Shihāb al-Dīn 'Umar al-Suhrawardi (d. 1234), who brought the insignia of fütüvvet to the Rum Seljuq sultanate in 1221 on behalf of the Abbasid caliph. ${ }^{100}$ The "formal « invitation to fütüvvet coincided with a renewed interest in civic governance, which necessitated the formulation of inclusive and exclusive urban conduct with respect to the practice of faith, intercommunal relations and the affairs of the urban market. ${ }^{101}$

91 Blessing, Rebuilding Anatolia, 183.

92 Blessing, Rebuilding Anatolia, 193. On the distinction between Sufis and akhīs, see Selçuk, Suggestions.

93 An inscription from Konya indicates a Greek Christian akhi. Taeschner, Achis in Anatolien, 20.

94 Aflākì mentions Armenian akhi-like brotherhoods in his Manāḳib al-'Árifīn I, 3 ed. Yazıcı 463, 489. Two fütüvvet manuals authored by Hovhannes Pluz (d. 1293), an Armenian priest of the Anatolian city of Erzincan have been translated and interpreted by Goshgarian; see Goshgarian, Armenian texts on fotovvat, 82-214.

95 Vryonis, Byzantine guilds, 314; idem, Circus factions, 56, 285-286.

96 Hillenbrand, Seljuk court at Konya, 168.

97 Goshgarian, Futuwwa in thirteenth-century Rum and Armenia, 228;

98 Goshgarian, Diversity in the Medieval Middle East, 144.

99 Goshgarian, Diversity in the Medieval Middle East, 151, 155-157.

100 Goshgarian, Futuwwa in thirteenth-century Rūm and Armenia, 250.

101 Goshgarian, Opening and closing, 37. 
Among the oldest extant manuscripts, a fütüvvet manual written for the Turkish-speaking Anatolian audience by Yahyā b. Halī b. Çoban, al-Burgāzì mentions apposite conduct and morals in economic transactions that guided those who entered the fütüvvet-akhi tradition in the thirteenth century. ${ }^{102}$ As an influential text of this period, a closer look at al-Burgãzìs manual illustrates expectations from an ideal $a k h \bar{\imath}$ in the fütüvvet path. Eligibility criteria identify people of certain character traits and members of professions that cannot be admitted to fütüvvet. While lack of morals in the general sense determines a good portion of these criteria, people of the market who are denied entry to fütüvvet are the criers of prices, collection agents, hoarders, and those who lack the knowledge to do their job. ${ }^{103}$

In a similar manner, al-Burgāzì provides a detailed account of the qualities of a respectable $a k h \bar{i},{ }^{104}$ who is a generous, chaste, and humble man making a living from a craft or a profession, and sharing his income with those in need. ${ }^{105}$ The "tree of fütüvvet " grows in the bosom of the novice (yiğit) in the path to becoming an akhi, if he has the attributes of loyalty, purity, reliability, piety, kindness, courage and modesty. ${ }^{106}$ The emphasis on honesty and modesty reverberates throughout the text, and is supported by quotations from the Qur'an, (XVII: 35): "And give full measure whenever you measure, and weigh with a balance that is true: this will be [for your own] good, and best in the end ${ }^{107}$ ordering the use of correct weights and measures regarding market transactions, as well as justice and equity in general; and praising charity and condemning conspicuous consumption:

O you who have attained to faith! Do not deprive your charitable deeds of all worth by stressing your own benevolence and hurting [the feelings of the needy], as does he who spends his wealth only to be seen and praised by men, and believes not in God and the Last Day: for his parable is that of a smooth rock with [a little] earth upon it and then a rainstorm smites it and leaves it hard and bare. Such as these shall have no gain whatever from all their [good] works: for God does not guide people who refuse to acknowledge the truth. ${ }^{108}$

102 Oldest manuscript: Fatih Millet Library, Ali Emiri Efendi catalogue, Şer'iyye no:1154/198. For the text and its analysis, see Gölpınarl, Burgāzī. While al-Burgāzìs manuscript was significantly (partly word for word) copied from a previous manual Tuhfat al-Vasāyā, by Ahmed b. Nakkaş İlyas, [Ahmed b. Nakkaş İlyas, 108a-l17b; Abdülbaki Gölpınarl, Fütüvvet Teşkilatı, 205-231], the text was also used by future contributors to the literature, namely the Turkish fütüvvet-nāme by Sheikh Hüseyin b. Sheikh Seyyid Gaybi (c. 1451-1481); Gölpınarl, Şeyh Seyyid Gaybi oğlu; an anonymous manuscript written in the fourteenth century and copied in 1610. [Ayasofya Library manuscript no. 2049, (108a-117b)]; and Miftāh al-Daqāiq fì Beyān al-Fütüvveti'l-Haqāiq, also known as Fütüvvetnāme-i Kebìr (1524) by Seyyid Muhammad b. al-Seyyid alā-al-Dīn al-Huseyniyy al-Razavī. Breebaart, Fütüvvet-nāme-i Kebīr, 203-215.

103 Al-Burgāzī, Fütüvvet-nāme, 22a-26a in Gölpınarlı, Burgâzî, 121-124.

104 "He is generous both in this world and in the other world; he does not neglect the daily prayers and practices the rituals of Islam; he abandons worldly pleasures, remaining celibate, does not yearn for high positions; he earns lawful income; he has a vocation, for without one, he cannot help the ones in need; he does not have over eighteen dirhems of silver as his savings; he is not ignorant and constantly seeks knowledge.« Al-Burgāzì, Fütüvvet-nāme, 28a.-43a in Gölpınarl, Burgâzî, 124-132.

105 Al-Burgāzī, Fütüvvet-nāme, 43b in Gölpınarl, Burgâzî, 132-133. The fourteenth-century traveler Ibn Bațtūṭa narrates that throughout his stay in Anatolia he was hosted by akhis is the towns he visited; see Ibn Bațtutata, Travels, 413-468, 426-427. Oya Pancaroğlu analyzes the hospitality of akhi brotherhoods in her article Devotion, hospitality and architecture, 60-72.

106 Al-Burgāzī, Fütüvvet-nāme, 27a in Gölpınarl, Burgâzî, 124.

107 Al-Burgāzī, Fütüvvet-nāme 65 a.-b. in Gölpınarl, Burgâzî, 145-146. Translation from: The Qur’ān, Surah al-Isrā' (The Night Journey) XVII: 35; Message of the Qur'än, trans. Asad, 423-424.

108 Al-Burgāzī, Fütüvvet-nāme, 43a. The Qur'ān, Surah II, 264; Message of the Qur'ān, trans. Asad, 60. 
Fütüvvet manuals continued to circulate in the Ottoman period, long after the prominence of the akhis disappeared with Ottoman centralization. ${ }^{109}$ It is noteworthy that in some of these later manuscripts, too, parallels between fütüvvet and commanding good are quite pronounced. ${ }^{110}$

\section{Conclusion}

This paper highlighted primarily prescriptive, descriptive, and narrative sources reflecting similar, discernable notions of economic morals from the late antique, middle Byzantine and later medieval periods. The basic assumption here is the impact of these notions on market-regulation concerns in Anatolia. Persistent warnings appear from Late Antiquity onwards against usury, hoarding, trickery, conspicuous consumption, profiteering, and price fixing. The promoted ideals are a just price, just value, just profit, value based on labor and risk, natural exchange, fighting poverty by charity, protecting sellers from enormous damage, and self-sufficiency. Perceptions of the market and merchants' profit evolved over time from the Greek patristic to middle and Late Byzantine times, eventually gaining relative respect for merchants' profit. Resilient in balancing the market with moral teachings, the Byzantine experience displayed the picture of a state-led economy with considerable success in fulfilling general concerns with justice.

Economic morals that impacted Anatolian markets in the later medieval period of political competition among various powers were notably shaped by the principle of commanding good, and fütüvvet ethics that guided urban artisanal brotherhoods. Commanding good provided a clear framework that strictly forbade usury, hoarding, collusion, speculation, and trickery. The Islamic perception of the market did not focus on sin and salvation regarding the corruptive potential of commerce, contrary to Christian notions. The concepts of promoting public good and preventing public harm provided the general framework for policymakers, based on Islamic legal positions elaborated by Muslim scholars. Openly banned by Islamic schools of law, price regulations were only tolerated in times of famine or drought, until the later Ottoman period when price fixing became regular and codified. Fütüvvet, on the other hand, which taught chastity, generosity, modesty, piety, industriousness, and service, had counterparts among Greek and Armenian Christian communities. This picture attests both to the complexity of the period, and to the congruence of different facets of medieval economic morality. Inequalities born from market exchange were fought by a moral realm created by jurists based on Islamic Law. Moral principles were further influenced by the concepts of the circle of justice, the quadripartite society, and household management, according to which, continuity of production, taxation, provisioning and protection of the common people were intertwined under the rubric of justice.

109 For a concise assessment of akhis in Ottoman times, see Faroqhi, Artisans of Empire, 1-2, 28-31. How much injunctions of fütüvvet treatises shaped the actual behavior among institutional and hierarchical Ottoman guild members of the early-modern period is questioned by Yi, Rich artisans and poor merchants, 196-199.

110 Such as Miftāh al-Daqā'iq fì Bayān al-futuwwa wa'l Haqā'iq, known by the title Fütüvvetnäme-i Kebìr, written in sixteenth-century Bursa by Shaykh Seyyid Huseyn ibn Shaykh Seyyid Gaybì, which explains the fundamental knowledge necessary to distinguish between what is "permissible and despicable«, notions of just price, honesty in trade, proper weights and measures, fair profit, patron saints, and proper religious conduct in the market. For an analysis of notions of economic morals in this manual, see Breebaart, Fütüvvet-nāme-i Kebīr, 203-215; idem, Turkish Futuwwa Guilds. On parallels between fütüvvet and hisba, see also Selçuk, Suggestions, 106-107. 
The holy scripture and traditions, within their respective historical contexts, provided the moral teachings that aimed to guide individuals in their economic and commercial endeavor. Economic morals overall, however, were also shaped by pre-modern agricultural tributary imperial systems that strove to continue their livelihood through market regulation, provisions and maintaining social justice. The present study, therefore, underlines the two facades of market regulation: religious moral teachings on the one hand, and the concerns of centralized states on the other. While these two facets suggest plausible organic relationships between relevant institutions and practices, similarity through comparison on the conceptual level is obvious. 


\section{References}

Abū Dāwūd Al-Sïistānī, Sunan Abì Dāwūd, Vol. 5, ed. Shu'ayb al-Arnāut and Muhammad Kāmil Qarahbalalī (Beirut, 2009). Accessed on 6 December 2020: sunnah.com/abudawud. Aflākī, Shams al-Ahmad, Manāḳib al-'Ārifiñn, ed. Tahsin Yazıcı (Ankara, 1976).

Ağır, Seven, From Welfare to Wealth: Ottoman and Spanish Grain Trade Policies in a Time of Change. Unpublished PhD Thesis (Princeton University, 2009).

Basil of Caesarea, Homilia dicta tempore famis et siccitatis. 325, 8, ed. J. P. Migne, Patrologia Graeca 31 (1857) 304-328.

Ibn Bațūța, The Travels of Ibn Batttuta A.D. 1325-1354, trans. and ed. H. A. R. Gibb, vol. 2 (Cambridge, 1962).

Blessing, Patricia, Rebuilding Anatolia after the Mongol Conquest Islamic Architecture in the Lands of Rüm, 1240-1330 (London, 2016).

Breebaart, Deodaat Anne, The Fütüvvet-nāme-i kebīr. A manual on Turkish guilds, Journal of the Economic and Social History of the Orient 15/1-2 (1972) 203-215.

Breebaart, Deeoodart Anne, The Development and Structure of the Turkish Futuwwa Guilds. Unpublished PhD thesis (Princeton University, 1961).

Bury, John Bagnell, A History of the Later Roman Empire from the Death of Theodosius I to the Death of Justinian A.D. 395-565, 2 vols. (New York, 1957).

Constantelos, Demetrios J., Byzantine Philanthropy and Social Welfare, (New Brunswick, NJ, 1968).

Cook, Michael, Commanding Right and Forbidding Wrong in Islamic Thought (Cambridge, 2001).

Crone, Patricia, Roman, Provincial and Islamic Law. The Origins of The Islamic Patronate (Cambridge, 2002).

Dagron, Gilbert, The Urban economy, seventh-twelfth centuries, in: Angeliki E. Laiou (ed.), The Economic History of Byzantium: From the Seventh through the Fifteenth Century (Washington, DC, 2002) 385-453.

De Nicola, Bruno, Letters from Mongol Anatolia: Professional, political and intellectual connections among members of a Persianised elite, Iran, Journal of the British Institute of Persian Studies (February 2018) 1-14. Accessed on 11 October 2021: doi.org/10.1080/05786 967.2018.1426189.

De Nicola, Bruno, On the outskirts of the Ilkhanate, in: Suzan Yalman and Filiz Yenişehirlioğlu (eds.), Cultural Encounters in Anatolia in the Medieval Period: The Ilkhanids in Anatolia, Symposium Proceedings (Ankara, 2019) 117-135.

Evans, James A. S., The Age of Justinian: The Circumstances of Imperial Power (London, 1996).

Faroqhi, Suraiya, Artisans of Empire Crafts and Craftspeople under the Ottomans (London, 2009).

Foster, Benjamin R., Agoranomos and Muhtasib, Journal of the Economic and Social History of the Orient 13 (1970) 128-144.

Frakes, Robert M., Late Roman social justice and the origin of the defensor civitatis, The Classical Journal 89/4 (1994) 337-348.

Frakes, Robert M., The Syro-Roman lawbook and the "Defensor Civitatis, « Byzantion 68/2 (1998) 347-355.

Gelzer, Heinrich, Leontios von Neapolis: Leben des Heiligen Johannes des Barmherzigen Erzbischofs von Alexandrien (Freiburg, 1893). 
Glick, Thomas F., Muhtasib and Mustasaf, A Case Study of Institutional Diffusion, Viator 2 (1971) 59-81.

Glick, Thomas F., New Perspectives on the Hisba and its Hispanic Derivatives, Al Qantara 13/2 (1992) 475-489.

Goshgarian, Rachel, Futuwwa in thirteenth-century Rum and Armenia: Reform movements and the managing of multiple allegiances on the Seljuk periphery, in: A. C. S. Peacock and Sara Nur Yıldız (eds.), The Seljuks of Anatolia: Court and Society in the Medieval Middle East (London, 2013) 227-263.

Goshgarian, Rachel, Opening and closing: coexistence and competition in associations based on futuwwa in late medieval Anatolian cities, British Journal of Middle Eastern Studies 40/1 (2013) 36-52.

Goshgarian, Rachel, Late Medieval Armenian texts on Fotovvat: Translations in context, in: Lloyd Ridgeon (ed.), Javanmardi: The Ethics and Practice of Persianate Perfection (London, 2018) 182-214.

Rachel Goshgarian, Diversity in the medieval Middle East inclusions, exclusions, supporters, and discontents, in: Lucia Volk (ed.), The Middle East in the World: An Introduction, Foundations in Global Studies (New York, 2015) 140-158.

Gölpınarlı, Abdülbaki. Burgâzî ve ‘Fütüvvet-Nâme’si, İktisat Fakültesi Mecmuası 15/1-4 (195356) $76-154$.

Gölpınarl, Abdülbaki. Şeyh Seyyid Gaybî Oğlu Şeyh Seyyid Huseyn'in 'Fütüvvet-Nâme'si, İktisat Fakültesi Mecmuası 17/1-4 (1955-56) 27-126.

Gölpınarlı, Abdülbaki, Islam ve Türk İllerinde Fütüvvet Teşkilatı ve Kaynaklar, İstanbul Üniversitesi İktisat Fakültesi Mecmuast 11/1-4 (1949) 6-354.

Hallaq, Wael B., An Introduction to Islamic Law (Cambridge, 2009).

Hallaq, Wael B., The use and abuse of evidence: The question of provincial and Roman influences on early Islamic law, Journal of the American Oriental Society 110/1 (1990) 79-91.

Hillenbrand, Carole, Rāvandì, the Seljuk court at Konya and the Persianisation of Anatolian cities, Mésogeios 25-26 (2005) 157-169.

Hodgson, Marshall G. S., The Venture of Islam, Vol 1, The Classical Age of Islam (Chicago, 1974).

Huitson, Toby, Stairway to Heaven: The Functions of Medieval Upper Spaces (Oxford, 2014).

Izdebski, Adam, Marcin Jaworski, Handan Üstündağ, and Arkadiusz Sołtysiak, Bread and class in medieval society: Foodways in Anatolia, Journal of Interdisciplinary History 48/3 (2018) 335-357.

İnalclk, Halil, The hub of the city. The Bedestan of Istanbul, International Journal of Turkish Studies 1/1 (1979-80) 1-17.

John of Nikiu, The Chronicle of John, Bishop of Nikiu, trans. from Zotenberg's Ethiopic Text by Robert H. Charles (London, 1916).

Khū' ì, Ḥusām al-Dīn, Rusūmü'r-resā'il ve nücūmü'l-feżāàil, Gunyetü'l-kātib, ed. Adnan Sadık Erzi (Ankara 1963).

Kırımlu Hafiz Hüsam, Teressül, ed. Şinasi Tekin, Sources of Oriental Languages and Literatures 87 (Hacı Seliamağa Library, Nurbanu catalogue, manuscript no: 122/5) (Cambridge, 2008).

Konevî, Teḳârîrü’l-menâșıb Türkiye Selçukluları Hakkında Resmî Vesikalar, Osman Turan (ed.) (Ankara, 1958).

Kallek, Cengiz, Narh, Islam Ansiklopedisi 32 (2006) 387-389. 
Kafadar, Cemal, When Coins Turned into Drops of Dew and Bankers Became Robbers of Shadows: Ottoman Economic Imagination at the end of the Sixteenth Century. Unpublished $\mathrm{PhD}$ thesis (McGill University, 1986).

Kelly, John Norman Davidson, Golden Mouth: The Story of John Chrysostom - Ascetic, Preacher, Bishop (Ithaca, NY, 1995).

Klein, Yaron, Between public and private: an examination of Hisba literature, Harvard Middle Eastern and Islamic Review 7 (2006) 41-62.

Koder, Johannes, Das Eparchenbuch Leons des Weisen (Vienna, 1991).

Kütükoğlu Mubahat S., Narkh, in: Peri Bearman et al. (eds.), Encyclopaedia of Islam 2

(Leiden, 2012) Accessed 11 October 2021: doi: dx.doi.org/10.1163/1573-3912_islam_ SIM_5801.

Laiou, Angeliki E., Trade, Profit, and Salvation in the Late Patristic and the Byzantine Period, in: Wealth and Poverty in Early Church and Society, ed. Susan R. Holman (Grand Rapids, 2008) 243-266.

Laiou, Angeliki E., The Byzantine economy: An overview, in: Angeliki E. Laiou (ed.), The Economic History of Byzantium (Washington, DC, 2002) 1162-1164.

Laiou, Angeliki E. and Cecile Morrison, The Byzantine Economy (Cambridge, UK, 2007).

Lange, Christian, Hişba and the problem of overlapping jurisdictions, Harvard Middle Eastern and Islamic Review 7 (2006) 85-107.

Lange, Christian, Legal and cultural aspects of ignominious parading (tashhir) in Islam, Islamic Law and Society 14 (2007) 81-108.

Lange, Christian, Justice, Punishment and the Medieval Muslim Imagination (Cambridge, 2008).

The Life of Saint Basil the Younger: critical edition and annotated translation of the Moscow version, ed. Denis F. Sullivan, Alice-Mary Talbot, Stamatina McGrath, Dumbarton Oaks Studies 45 (Washington, DC, 2014).

Magdalino, Paul, Studies on the History and Topography of Byzantine Constantinople (Aldershot, 2007).

Ibn Māja, Muhammed b. Yazīd, (d. 887) Sunan Ibn Māja, vol. 2, ed. Muhammed Fuad 'Abd al-Bāqì (Cairo, 1972). Accessed on 6 December 2020: sunnah.com/ibnmajah.

Magoulias, Harry, The Lives Of The Saints As Sources Of Data for the History of Commerce in the Byzantine Empire in the Vith and Viith Century. Unpublished $\mathrm{PhD}$ thesis (Harvard University, 1961).

Mango, Marlia Mundell, The commercial map of Constantinople, Dumbarton Oaks Papers 54 (2000) 189-207.

Maniatis, George C., Organization, market structure, and modus operandi of the private silk industry in tenth-century Byzantium, Dumbarton Oaks Papers 53 (1999) 263-332.

Maniatis, George C., The domain of private guilds in the Byzantine economy, tenth to fifteenth centuries, Dumbarton Oaks Papers 55 (2001) 339-369.

Mayer, Wendy and Pauline Allen, John Chrysostom (London, 2000).

Mayer, Wendy, Poverty and generosity toward the poor in the time of John Chrysostom, in: Susan R. Holman (ed.), Wealth and Poverty in Early Church and Society (Grand Rapids, 2008) 140-158.

Melville, Charles, Anatolia under the Mongols, in Kate Fleet (ed.), The Cambridge History of Turkey, v.1 Byzantium to Turkey 1071-1453 (Cambridge, 2009) 51-101.

Merianes, Gerasimos and George Gotsis, Managing Financial Resources in Late Antiquity, Greek Fathers' Views on Hoarding and Saving (London, 2017). 
The Message of the Qur'ān, trans. Muhammad Asad (Gibraltar, 1997).

Mottahedeh, Roy and Kristen Stilt, Public and private as viewed through the work of the muhtasib, Social Research 70/3 (2003) 741-742.

Pitarakis, Brigitte, The Byzantine marketplace: A window onto daily life and material culture in: Paul Magdalino, Nevra Necipoğlu and Ivana Jevtic (eds.), Papers from the third international Sevgi Gönül Byzantine Studies Symposium İstanbul 24-27 June, 2013 (Istanbul, 2016) 211-233.

Pancaroğlu, Oya, Devotion, hospitality and architecture in medieval Anatolia, Studia Islamica 108 (2013) 48-81.

Peacock, A. C. S., Islam, Literature and Society in Mongol Anatolia (Cambridge, 2019).

Rapp, Claudia, Holy Bishops in Late Antiquity: The Nature of Christian Leadership in an Age of Transition (Berkeley, 2005).

Sabra, Adam, 'Prices Are in God's Hands': The theory and practice of price control in the medieval Islamic world, in: Michael Bonner, Mine Ener and Amy Singer (eds.), Poverty and Charity in Middle Eastern Contexts (Albany, 2003) 73-93.

Sariyannis, Marinos, A History of Ottoman Political Thought Up to the Early Nineteenth Century (Leiden, 2019).

Selçuk, İklil, Onbeşinci yüzyll Bursa örneğinde Osmanlı şehir ekonomisi ve yönetim özellikleri üzerine in: Ümit Ekin (ed.), Prof. Dr. Özer Ergenç'e Armağan (Istanbul: 2013) 351362.

Selçuk, İklil, Suggestions on the social meaning, structure and functions of akhi communities and their hospices in medieval Anatolia, in: Patricia Blessing and Rachel Goshgarian (eds.), Architecture and Landscape in Medieval Anatolia, 1100-1500 (Edinburgh, 2017) 95113.

Selçuk, İklil, Ottoman market-regulation and inspection in the early-modern period, ADALYA 24 (2021).

Al-Shayzarī, 'Abd al-Raḥmān b. Naṣr, Kitāb Nihāyat al-rutba fì țalab al-ḥisba, ed. Al-Sayyid al-Bàz al-'Arinī (Cairo, 1946).

Al-Shayzarī, Nihāyat al-rutba fi țalab al-hisba (The Utmost Authority in the Pursuit of Hisba), trans. R. P. Buckley, Journal of Semitic Studies Supplement 9 (Oxford, 1999).

Singer, Amy, Charity in Islamic Societies (Cambridge, 2008). Singer, Amy, Nina Ergin and Christoph K. Neumann (eds.), Feeding People, Feeding Power: Imarets in the Ottoman Empire (Istanbul, 2007)

Stilt, Kristen A., Islamic Law in Action: Authority, Discretion, and Everyday Experiences in Mamluk Egypt (Oxford, 2011).

Taeschner, Franz, Beiträge zur Geschichte der Achis in Anatolien (14.-15. Jht.) auf Grund neuer Quellen, Islamica 4 (1929) 1-47.

Tekin, Oğuz, Balance Weights in the Aegean World. Classical and Hellenistic Periods (Istanbul, 2016).

Tekin, Oğuz, Charm of the Market. Shopping in the Mediterranean throughout History, translated by Michael D. Sheridan (Antalya, 2019).

Three Byzantine Saints, Contemporary Biographies of Daniel the Stylite, St Theodore of Skyeon, and St John the Almsgiver, ed. and trans. Elizabeth Dawes and Norman H. Baynes (New York, 1977).

Al-Tirmidhī, Muhạmmad b. 'Īsā, Al- Jāmi'al-Kabìr, 2, ed. Bashshār 'Awwād Ma'rūf (Beirut, 1998). 
Trépanier, Nicolas, Foodways and Daily Life in Medieval Anatolia, A New Social History, (Austin, 2014).

Ibn al-Ukhuwwa, Ḍiyā' al-Dīn Muḥammad b. Muḥammad b. Aḥmad al-Qurashī al-Shāfi'ì, Ma'àlim al-qurba fì aḥkàm al-ḥisba, ed. Reuben Levy (Cambridge, 1938).

Wittmann Richard, The Muhtasib in Seljuq times: Insights from four chancery manuals, Harvard Middle Eastern and Islamic Review 7 (2006) 108-128.

Ylldırım, Onur, Pious foundations in the Byzantine and Seljuk states: A comparative study of philanthropy in the Mediterranean world during the late medieval era: The Diataxis of Michael Attaleiate and the Waqfiyya of Celaleddin Karatay, Rivista degli studi orientali 73 , $1 / 4$ (1999) 27-52.

Ylldız, Sara Nur, Post-Mongol pastoral policies in eastern Anatolia during the Late Middle Ages, in: Deniz Beyazit and Simon Rettig (eds.), At the Crossroads of Empires: 14th-15th Century Eastern Anatolia. Proceedings of the International Symposium held in Istanbul, 4th-6th May 2007, Varia Anatolica 25 (Istanbul, 2012) 27-48.

Ylldız, Sara Nur, Mongol Rule in Seljuk Anatolia: the Politics of Conquest and History-Writing, 1243-1282 (Leiden, 2009).

Yi, Eunjeong, Rich artisans and poor merchants? A critical look at the supposed egalitarianism in Ottoman guilds, in: Suraiya Faroqhi (ed.), Bread from the Lion's Mouth (New York, 2015) 194-216. 